by the American Institute of Graphic Arts. To the American observer the particular interest of the publication lies in the manner in which a continental museum has visualized and presented the interrelationship of the private press movement in England and America, and which presses and personalities have been selected as particularly significant.

An excellent view of the further development of these connections, and a first rate biographical document about the dean of American book designers is Bruce Rogers' PI. Much of the personal history of Rogers, who is now in his eighties, is a living demonstration of Anglo-American relations. His work for the university presses of Oxford and Cambridge, his close contact with the English Monotype Corporation and his long friendship with leading British bookmen (among them Shaw and Lawrence of Arabia) find colorful reflection in the pages of $P I$. The men he speaks of, incidentally, are of a different group and another generation from those mentioned by Powell in his Alchemy, which only goes to prove that these connections transcend the personal and the accidental. But we read also much about some of the great figures in the world of books and printing on this side of the Atlantic. Henry Watson Kent, Fred Goudy, William Edwin Rudge, Frederic Warde-here are some of the names of men no longer with us who come to life here.

A good many of the pieces included in this "Hodge-Podge" have been published previously and some of them will be familiar to some, and others to others. But their collected presentation in chronological order gives this $P I$ the quality of an important biographical contribution about one of the great Americans of the twentieth century. His commentary on his own work is always worth reading and one only regrets that circumstances have made BR much more articulate about the products of his middle and later years (the Homer, the Shakespeare, the two Bibles) than about much of his equally significant earlier work in book design.

The prose of Bruce Rogers is something special and rare in its self-satirical humor, its occasional deliberate archaisms, in its use of the gentle pun-but above all in the careful choice of words and the sensitive and dignified phrasing. But what else could one expect from the man who once wrote the following (to the editor of the Saturday Review, October 29, 1927):

The press holds up a mirror to the author in which he may see himself clearly. If the paper, type, and composition are carefully chosen and harmonious, the author sees his work in a new guise. He may feel keen pride or shame. He hears a firmer, more detached voice than his own-an implacably just voice-articulating his words. Everything weak, trivial, arbitrary, or in bad taste that he has written is pointed up and comes out in clear relief. It is at once a lesson and a splendid thing to be beautifully printed.Hellmut Lehmann-Haupt, New York.

\section{Recent Foreign Books on the Graphic Arts, Bibliography, and Library Science}

The very nature of reference work demands that a special compilation of reference books be available for each country. On the other hand, such works as Winchell and Malclès are welcome as additional tools for the reference librarian in countries where languages other than English and French are spoken. The Handbuch der bibliographischen Nachschlagewerki (Frankfurt on the Main, Vittorio Klostermann, 1954; 258 p.; DM21.50) by Wilhelm Totok and Rolf Weitzel is not as extensive as Winchell and Malclès; but it contains a thoughtful selection of titles and both serves the purposes of the German librarian and amplifies Winchell for the English-speaking librarian.

Titles are arranged in classified order with brief introductory essays preceding each major section. Entries follow the Prussian Instruktion, and fully adequate bibliographical information is provided. Whenever necessary there is a brief annotation, but all such annotations are confined to essential information. Critical comment is carefully avoided, and the user must turn to other sources for evaluation of the various work included. There is an author, title, and subject index, the latter confined to an index of the classification and countries (with pertinent subjects listed under each country).

There is a high degree of accuracy in the recording of foreign titles, an important element in any checklist of reference books. A 
check of a few American titles indicates that the entries are most probably based on actual examination of the books. A particularly attractive feature is the adequate coverage of Slavic materials, although there is some room for expansion in the field of Hispanic studies. A regular supplement such as that for Winchell would be useful.

The second fascicle of the Bibliographie historischer Zeitschriften, 1939-195I (Marburg Lahn, Otto Rasch, I953; 22 I p.) compiled by Heinrich Kramm for the Westdeutsche Bibliothek covers historical periodicals in the British Isles, the Low Countries (including Luxembourg), France, Portugal, Spain, and Italy. The first fascicle covered Germany, Switzerland, and Austria. This bibliography included periodicals current in I939 (with subsequent title changes indicated) as well as new ones. General periodicals are grouped in classifications, and local historical journals are arranged alphabetically by territory covered. There is an alphabetical index.

The truly monumental project under way at the Westdeutsche Bibliothek is the new edition of the Gesamtverzeichnis der ausländischen Zeitschriften (GAZ), of which the checking copies are now being circulated in fascicles throughout West Germany. When this great work is complete it will prove to be invaluable to serials workers everywhere for acquisition, cataloging, and reference purposes. Even though it will be a union catalog for West German libraries only, it will fill many needs created by the lack of a new Union List of Serials in a single alphabet. As Totok and Weitzel point out, a particularly urgent need is a new edition of the old Gesamt-Zeitschriften-Verzeichnis (GZV) of I9I4, or at least of the list of German periodicals contained in it. The unusual vitality of West German librarianship may well bring this need to reality.

In I95 I the Max Hettler Buchbinder-Verlag in Stuttgart published Ernst Kyriss' Verzierte gotische Einbande im alten deutschen Sprachgebeit (I59 p.) incorporating the results of a life-time of study of this important aspect of the history of the book. One reviewer criticized the book for not being illustrated. Actually Mr. Hettler deserved the only the gratitude of scholars for having been willing to undertake any publication at all in such a relatively specialized field; but he did plan two additional volumes of illustrations at intervals of two or three years. The first volume of illustrations appeared late in 1953 ( 185 p., incl. I 52 plates) and covers the first three parts of the text volume (bindings identified with monasteries, with binders known by name, and with initials or armorial bearings). Illustrations for the final and largest part of the text volumes, listing the work of unidentified binders, will appear in the last volume.

This first volume of illustrations is everything that a student of binding could hope for. No publisher could undertake to reproduce all of the 7,000 different stamps which Kyriss identified (although publication on microcard might be feasible, since rubbings and photographs of bindings show up quite well in this medium). Therefore only the most frequently used stamps were reproduced and they were numbered according to the frequency of their appearance. A few other unusual stamps are reproduced and are designated by letter. The 748 stamps which appear in this volume make it possible to identify virtually all the bindings which may fall into the categories covered by the first three sections of the text volume. All stamps are reproduced in their original size. For nearly every group there is a full page illustration of one cover with the name of the library, the call numbers, and the size in millimeters. A few covers had to be selected from private collections in view of the rarity of well preserved bindings, and in a few cases rubbings instead of photographs were used. In the case of binderies identified from books in libraries of Praha and Olomouc illustrations of full covers were unavailable.

Max Hettler might well be satisfied with a profitable business in the publication of the Allgemeiner Anzeiger für Buchbindereien and practical manuals for binderies, but instead he has taken the initiative to publish works such as Verzierte gotische Einbände and a valuable new series of "Meister und Meisterwerke der Buchbinderkunst" edited by G.A.E. Bogeng. The first volume in the series was a study of Jakob Krause by Ilse Schunke, and the second is Bogeng's Emanuel Steiner (1954; 63p., incl. I6 plates, each portraying a separate binding by Steiner). Bogeng gives a penetrating analysis of the career of this 
noteworthy practitioner and teacher of binding who stands in the front ranks of his craft in the twentieth century. Born in Basel in 1876 as the son of the master binder Edward Steiner, Emanuel Steiner came to maturity at precisely the time when the noteworthy revival of art binding began to take root in German-speaking countries, and he was in the forefront from the beginning. A study of Emanuel Steiner's life and work is a useful introduction to twentieth century trends in fine bookbinding.

Hettler's list of practical manuals on all aspects of binding is a long one, but no title could be more useful to hand binders than the third edition of Fritz Wiese's Der Bucheinband; eine Arbeitskunde mit Werkzeichungen, ( 1953 ; 408p., incl. 245 line drawings of binding processes in the text). Every step of the binding process is described in meticulous detail, in clear and simple language, and so well illustrated that it has a place on the shelf even of binders whose acquaintance with the language is limited. College and reference libraries will find frequent occasion to consult it in dealing with their conservation problems.

It is difficult to overemphasize the importance of a knowledge of the history of paper not only for binders but also for librarians and others concerned with the physical book. While we have significant and useful works in English by Dard Hunter and in German by Armin Renker, the new manual by Gustaf Clemensson, Papperets historia intill $I 880$ (Stockholm, Hugo Gebers Förlag, I953; "Gralska Institutets Skriftserie," no. 8, 99p.; $\mathrm{Kr} .7 .50$ ) is useful as perhaps the best short summary of the subject. There are several notes on the history of paper in Sweden which are not in the general books by Hunter and Renker. The 28 illustrations are well selected and reproduced.

George Svensson's Modern Svensk Bokkonst (Stockholm, Sällskapet Bokvännerna, I953; "Bokvännens Bibliotek," no. 15; 254 p.; Kr. $48.00)$ is an important study of the art of the book in Sweden for the last six decades. Beginning with the work of Carl Larsson as an illustrator and of Waldemar Zachrisson and the Lagerström brothers (Carl and Hugo) as typographers in the nineties, Svensson traces illustration, design, printing, and binding ( art and commercial) in Sweden up to the present day. The author was editor of Bonniers Lit- terära Magasin for many years, and virtually all significant modern Swedish books have passed through his hands. He is also a member of the Svensk Bokkonst jury to select the twenty-five books of the year and a trained historian of art. Svensson's facility with his subject as well as his easy and unadorned style make Modern Svensk Bokkonst excellent reading. As a result of the some 150 illustrations, of which a fifth are in color, the book is accessible and useful whether or not the reader can handle the text. There is an index including artists and authors.

Mord $i$ Biblioteket (Stockholm, Sällskapet Bokvännerna, I953; "Bokvännens smâskrifter," no. 9; 83 p.)-“murder in the library"-is the blood-curdling title of a book by $T$ age la Cour in another series by the same publisher. It is an urbane and informed study of the mystery story in English from Poe to Faulkner. La Cour is a special aficionado of this branch of the delicious vice, and he writes about Gypsy Rose Lee with the same enthusiasm that he cherishes for Wilkie Collins and Edgar Wallace. The select library of something over a hundred mystery stories in the appendix might well be studied for purposes of book selection.

In the field of Scandinavian book arts the gift book issued at the turn of the year has a special place. ${ }^{1}$ While these little pieces are listed and discussed in the January or February numbers of $D e$ grafiske Fag, Grafiskt Forum, and Nordisk Boktryckarekonst, at least one may be given special mention here. It is H. P. Rohde's translation of selections from Thomas Bewick's Memoirs ( 1953; I 56 p.) distributed by Hansens Bogtrykkeri, Holbergsgade 20, Copenhagen). The charming introduction by Rohde and the numerous fine reproductions of Bewick's engravings will give this volume a place on the shelves of the growing clan of Bewick collectors as well as in graphic arts collections. 1953, by the way, was the bicentennial of Bewick's birth.

An important new series for libraries is the "Beiträge zum Buch und Bibliothekswesen" edited by Carl Wehmer for Otto $\mathrm{Harrassowitz}$ of Wiesbaden. Actually it is a continuation of the "Sammlung bibliothekswissenschaftlicher Arbeiten" formerly issued by Harrassowitz

\footnotetext{
1 See, Thompson, Lawrence S., "Danish Christmas Books," Notes on Printing and the Graphic Arts, I (1953), 76-79.
} 
in Leipzig. The first three volumes are (1) Peter Karstedt, Studien zur Soziologie der Bibliothek (1954, viii, 97 p.; DM 10); (2) Rudolf Blum, Der Prozess Fust gegen Gutenberg (1954; vi, I I8p.; DMi6); and (3) Georg Leyh, Aus 40 Jahren Bibliotheksarbeit: kleine Schriften (1954; viii, 26I p.; DM24). The fourth volume will be Friedrich Adolf Schmidt-Künsemüller, $W i l-$ liam Morris und sein Einfluss auf die moderne Buchkunst. Although Karstedt's work will be of primary interest to public librarians, it contains many sapient observations on the social function of the library in general. The importance of the others is readily apparent from the title.-Lawrence S. Thompson, University of Kentucky Library.

\section{German Reference Books}

Lexikon des Buchwesens. Herausgegeben von Joachim Kirchner. Band II: L-Z. Stuttgart, Hiersemann Verlag, 1953. Pp. 406-927. DM 36 (V. I and V. II together, DM 64).

Jahrbuch der Auktionspreise für Bücher und Autographen; Ergebnisse der Auktionen in Deutschland, Holland, Osterreich und in der Schweiz. Hamburg, E. Hauswedell \& Co., I950-date. V. II, I952. $\mathrm{xx}, 428 \mathrm{p}$. V. I11, I953. xx, 348p. DM 48 per volume.

The second volume of Joachim Kirchner's Lexikon des Buchwesens completes a work that every bookman-librarian, collector, bookseller, or publisher-needs on his desk. It is gratifying to note that this volume, like the third volume of the Löffler-Kirchner Lexikon des gesamten Buchwesens, contains a classified index arranged under twelve major headings and numerous sub-heads. Even more gratifying is the price for the two volumes (DM 64), especially when we see the old Löffler-Kirchner advertised for sixty dollars and more in antiquarian catalogs.

Like the first volume, the second is considerably abbreviated by comparison with the L-Z section of Löfler-Kirchner. However, the some 4,000 articles in Kirchner's two volumes contain the same basic information that may be found in the older work, and judicious use of the classified index facilitates the location of information consolidated from specific headings into more general ones.
Kirchner's alertness and familiarity with professional and technical literature is amply proven by bibliographical reference to articles and books that appeared in 1953. Basic bibliographical literature from all languages is cited; and if a captious reader is apt to cite an occasional omission, any such minor delinquency (to which all bibliographers are subject) is relatively unimportant.

One curious inconsistency will surely cause a minor titter at the next meeting of the Amherst College board of trustees: On p. 253 (volume I) it is stated that Henry Clay Folger presented his collection to the Library of Congress, and on p. 715 (volume II) it is stated that he presented it to the city of Washington, D.C. However, such deficiencies are fewer in number than they are in most comparable reference works.

The second and third volumes of the Jahrbuch der Auktionspreise für Bücher und Autographen have firmly established the value of this Hauswedell publication. Auction records for West Germany, the Netherlands, Austria, and Switzerland are included. Eighty sales are recorded for 195I, one less than for 1952. However, some of the auctions are for art objects and antiques, and such catalogs are recorded only to show the full picture of the activities of firms that sell books and autographs as well as works of art.

There are separate alphabets for books and autographs. Each of the two volumes contains a valuable essay by the well known Bavarian antiquarian bookseller Bernhard Wendt. There are also lists of booksellers' trade associations in all countries, special fields of various important antiquarian dealers, and addresses of firms which have ads in the Jahrbuch.

The minimum price for any item listed in the Jahrbuch is DM 25. Descriptions are as adequate as possible when based on auction catalogs. However, the hard-pressed dealer cannot always be as generous with information as the library cataloger with all the wonderful space on his three by five, and a few entries are slightly unclear (through no fault of the compiler, and no more than in comparable English and American works). Volume III has a few innovations: reference to bibliographical descriptions in some cases (e.g., incunabula), the number of the item in 